\title{
GEOSPATIAL ASSESSMENT OF BIOENERGY LAND USE AND ITS IMPACTS ON SOIL EROSION IN THE U.S. MIDWEST
}

William M. SooHoo, wsoohoo@email.sc.edu; *Cuizhen Wang, cwang@ mailbox.sc.edu; Huixuan Li, huixuan@email.sc.edu Dept. of Geography, University of South Carolina, Columbia, SC 29208, USA

\section{ABSTRACT}

Agricultural land use change, especially corn expansion since 2000s, has been accelerating to meet the growing bioenergy demand of the United States. This study identifies the environmentally sensitive lands (ESLs) in the U.S. Midwest using the distance-weighted Revised Universal Soil Loss Equation (RUSLE) associated with bioenergy land uses extracted from USDA Cropland Data Layers. The impacts of soil erosion to downstream wetlands and waterbodies in the river basin are counted in the RUSLE with an inverse distance weighting approach. In a GIS-ranking model, the ESLs in 2008 and 2011 (two representative years of corn expansion) are ranked based on their soil erosion severity in crop fields. Under scenarios of bioenergy land use change (corn to grass and grass to corn) on two land types (ESLs and non-ESLs) at three magnitudes (5\%,10\% and $15 \%$ change), this study assesses the potential environmental impacts of bioenergy land use at a basin level. The ESL distributions and projected trends vary geographically responding to different agricultural conversions. Results support the idea of re-planting native prairie grasses in the identified High and Severe rank ESLs for sustainable bioenergy management in this important agricultural region.

4 Keywords: bioenergy, corn expansion, RUSLE, soil erosion, environmentally sensitive land (ESL) 


\section{INTRODUCTION}

2

Since the mid-2000s, corn acreage in the U.S. Midwest has expanded immensely to satisfy the growing demand for bioenergy production. Domestic ethanol consumption was 6.1 billion liters in 2000 and soared to 54.9 billion liters in 2015 (ERS 2016). Upon the United States Department of Agriculture (USDA) crop census, corn acreage reached a historic record of 37.9 million ha in 2007 and the $2^{\text {nd }}$ highest of 37.3 million ha in 2011 (Wallander et al. 2011; Brown et al. 2013). The intensified agricultural land use raises concerns about soil erosion, runoff, and ecosystem healthiness (Park et al. 2011). Soil erosion, especially, has been a significant issue in the Midwest as it caused dramatic destruction to croplands and reduction of crop production (Kort et al. 1998).

These concerns are amplified in environmentally sensitive lands (ESLs), i.e. areas prone to soil erosion, important to biodiversity and hydrology of the watershed (Ndubisi et al. 1995). Several conservation policies have been implemented across the United States, including the Conservation Reserve Program (CRP) in 1985, the Conservation Security Program (CSP) in 2002 and the CRP-refined Conservation Reserve Enhancement Program (CREP) in 2005. These conservation acts have converted over 12 million hectares of croplands back to permanent green covers in the designated ESLs (Allen and Vandever 2003).

To leverage bioenergy demand, environment conservation and food safety, studies have been conducted to test native prairie grass as an alternative bioenergy source. In 1991 the Department of Energy designated switchgrass (Panicum virgatum L.) as a model crop for biofuel (Wright 2007). Research since then has shown positive feedbacks of utilizing switchgrass and other prairie grasses for biofuel feedstock (Vogel et al. 2002), erosion control (Das et al. 2004), water quality and biodiversity 
1 improvement (Smeets et al. 2009). However, conversion technologies of perennial grass,

2 e.g. releasing sugars from cellulose to be fermented into ethanol, have been inefficient

3 and expensive to meet the biofuel need (Somma et al. 2010), which limits the re-

4 establishment of prairie grasses in the Midwest (Wang et al. 2014).

5 Wetlands and waterbodies are an important component of the regional

6 environment. Wetlands provide crucial habitats for many species and contribute to

7 hydrological health of a region (Yang et al. 2016). Soil erosion, on the other hand, results

8 in excess sediment to downstream waterbodies and wetlands, reducing their suitability for

9 flood mitigation (Pandey et al. 2007). Along with excess sediment, agricultural chemicals

10 and nutrients degrade water quality and harm wetland ecosystems (Kouli et al. 2009).

11 Areas closer to wetlands and waterbodies contribute more to environmental sensitivity of

12 the region. Therefore, one important way to maintain wetland functionality is to limit the

13 amount of soil eroded, transported and deposited in these areas.

14 The Universal Soil Loss Equation (USLE) is one of the most widely accepted

15 empirical models to simulate annual soil loss (Wischmeier and Smith 1960). With the

16 same equation, the Revised USLE (RUSLE) improved the input factors such as better

17 cover-management categorization, new slope calculation and new conservation-practice

18 values (Wischmeier and Smith 1978; Renard et al. 1991). William and Berndt (1977)

19 developed the Modified USLE (MUSLE) to predict sediment yield on a storm event

20 basis, and Mitasova et al. (1996) developed the USLE-3D for complex terrains. Assisted

21 with remote sensing and geographic information systems (GIS) data, many studies have

22 utilized these USLE models to assess potential erosion in geographically diverse study

23 areas and different land use types and topographies (e.g., Kim et al. 2005; Kouli et al. 
1 2009; Parveen and Kumar 2012). Most of these studies deal with soil erosion and runoff

2 processes in watersheds. The USLE application for regional soil erosion and its impact to

3 wetlands and watersheds at a river basin scale has not been well documented.

$4 \quad$ Specifically for agricultural land uses, the USDA National Agricultural Statistics

5 Service (NASS) annually publishes the Cropland Data Layer (CDL) products classified

6 from 30-56 meter satellite imagery (NASS CDL 2016). Using these published crop maps

7 and environmental GIS layers, we performed a regional assessment of soil erosion by

8 adding a wetland/waterbody distance component into the RUSLE model. The ESLs in the

9 Midwest are identified and ranked, and their variations under intensified bioenergy land

10 use change are evaluated. These assessments will help us better understand the impacts of

11 bioenergy land use on soil erosion in this important agricultural region.

\section{2. MATERIALS AND METHODOLOGY}

\section{$13 \quad 2.1 \quad$ Study Region}

The Midwestern U.S. covers the northern part of the Mississippi River Basin

15 (Fig.1). Here we select two sub-basins as our study region - the Upper Mississippi River

16 Basin (0.49 million $\mathrm{km}^{2}$ ) and the Missouri River Basin (1.4 million $\left.\mathrm{km}^{2}\right)$. It encompasses

17 the Corn Belt in the east and the Great Plains in the west. As shown in the CDL map in

18 Fig.1, annual crops and perennial grasses dominate the study region. Corn and soybean

19 are the primary annual crops with typical corn-soybean rotation cycles. Other crops

20 include spring wheat in northern states, winter wheat in southern states, and

21 miscellaneous annual crops across the region. There is a relatively dry climate in the west

22 and moist climate in the east. According to precipitation data in the National Climatic 
1 Data Center (https://www.ncdc.noaa.gov/), annual rainfall of the study region ranges

2 from $500 \mathrm{~mm}$ in the Great Plains to $1,000 \mathrm{~mm}$ in the Corn Belt.

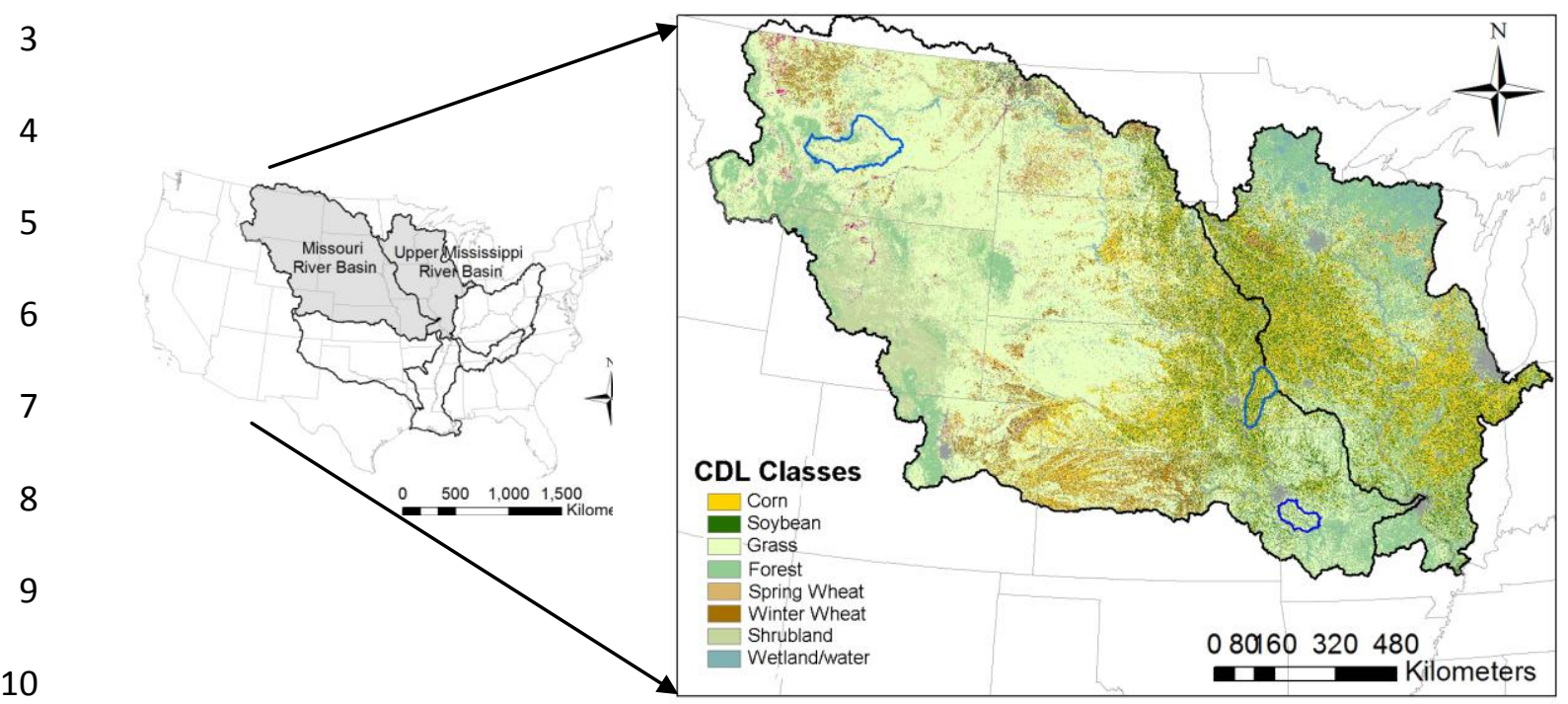

11 Figure 1: The study region consists of two sub-basins of the Mississippi River Basin. The CDL

12 map in 2011 displays major crops of the study region. The three test watersheds are also marked

in the CDL map.

Before European settlement in early 1800 s, the study region was predominantly

15 covered with native prairie grasses, mostly shortgrass prairie in the west and tallgrass

16 prairie in the east (Hopkins et al. 1995). Nowadays, the majority of prairie grasses have

17 been converted to row crops or more productive grass species in pasturelands (Wang et

18 al. 2014). Various efforts have been implemented to re-establish the native prairie grasses

19 of this region. In 2008, the USDA Biomass Crop Assistance Program (BCAP) Project

20 Area \#1 was established in 39 counties of Missouri and Kansas, which financially

21 supports landowners to plant switchgrass in their crop fields and to harvest for biomass

22 feedstock (Wang et al. in press). Environmental implications of these activities in the

23 study region have not been fully investigated.

\section{$24 \quad 2.2 \quad$ Data Sets}


2 layers, rainfall and runoff data are acquired from the DigitalCoast program sponsored by

3 National Oceanic and Atmospheric Administration (NOAA). The U.S. Soil Erodibility

4 and Soil Loss Tolerance (the maximum allowable soil loss per year), derived from the

5 SSURGO Soil Database at the National Resources Conservation Services (NRCS), are

6 downloaded from ArcGIS Online (ESRI 2015a, b). The digital elevation model (DEM) is

7 from the U.S. Geological Survey (USGS) Data Clearinghouse (Earth Explorer).

8 Agricultural land use/land cover data are acquired from the USDA CDL products.

9 Classification accuracies of CDL maps vary by states, with an overall 80-90\% in major

10 agricultural regions (Boryan et al. 2011). Two CDL maps, one in 2008 and the other in

112011 , are used in this study because of dramatic changes of corn production in these two

12 years (Wang et al. 2014; Brown et al. 2013). The wetland and waterbody data are also

13 extracted from the CDL maps.

14 To simplify the modeling process, all spatial data in Table 1 are resampled to 90-

15 meter grid cells. Different land covers and cropping activities cast different impacts on

16 soil erosion. Relying on field-specific CDL crop types, impact factors of land cover (C-

17 Factor) and erosion prevention (P-Factor) are assigned to each grid cell, based on

18 published literature listed in Table 1. More details are described in next section.

19 Table 1: Data sources in this study

\begin{tabular}{l|c|l}
\multicolumn{1}{c|}{ Data Sets } & Cell Size $(\mathbf{m})$ & \multicolumn{1}{c}{ Sources } \\
\hline DEM & 30 & USGS (Earth Explorer) \\
\hline Rainfall and Runoff & $\begin{array}{c}800 \\
(1981-2010 \\
\text { average })\end{array}$ & NOAA (DigitalCoast) \\
\hline Soil Erodibility & 30 & ESRI 2015a \\
\hline Soil Loss Tolerance & 30 & ESRI 2015b \\
\hline Land Cover & $56(2008)$ & USDA CDL \\
\hline
\end{tabular}




\begin{tabular}{l|c|l} 
Agricultural Land Use & $30(2011)$ & \\
\hline Cover (C-Factor), & & Nelson et al. 2014; NRCS 2004; \\
$\begin{array}{l}\text { Erosion Prevention (P- } \\
\text { Factor) }\end{array}$ & N/A & $\begin{array}{l}\text { Panagos et al. 2015; Sojka et al. } \\
\text { 1984; Ziv et al. 2012 }\end{array}$ \\
\hline
\end{tabular}

1

2

3

\subsection{Approaches}

A GIS ranking model was developed to extract the soil erosion severity (SES) and to rank the environmental sensitivity of each cell. In this model, the Revised Universal Soil Loss Equation (RUSLE) was modified with a new distance factor by taking the impacts of soil erosion to the nearest downstream wetland/waterbody into consideration.

The distance-weighted RUSLE was then applied to assess the ESLs in a variety of bioenergy land use change scenarios of the study region.

\section{Soil Erosion Model - Revised Universal Soil Loss Equation (RUSLE)}

The RUSLE calculates the potential soil loss from climatic, topographic, soil, and land use factors in a watershed (Wischmeier and Smith 1978):

$$
A=R \text { Factor } * \text { K Factor } * \text { LS Factor } * C \text { Factor } * P \text { Factor }
$$

where $A$ is the potential soil loss/ha/year; $R$ is the rainfall-runoff erosivity factor at a unit of 100 tons rainfall/ha/year relying on the 30-year average of precipitation records in $1981-2010 ; K$ is the soil erodibility factor at a unit of tons soil per 100 tons rainfall; $C$ is the cover factor and $P$ is the erosion prevention factor. $L S$ is the topographic factor that deals with slope length and steepness. With the DEM data, it is calculated as:

$$
\text { LS Factor }=\left(\text { Flow accumulation } \times \frac{\text { cell size }}{22.13}\right)^{.4} \times \operatorname{Sin}\left(\frac{\text { Slope }}{.0896}\right)^{1.3}
$$

where cell size $=90$ meters in this study, slope is in degrees, and flow accumulation is the number of cells from which water flows into the target cell.

The C-and P-Factors account for the influences of different land covers and crop management practices. The CDL map identifies more than one hundred crop types and 
1 rotation practices in the study region. In Table 2, we extract the $\mathrm{C}$ - and P-Factors of each

2 CDL class from published literature (as listed in Table 1). Corn/soybean and grass are the

3 primary concern of this study. Practically, corn and soybean are treated as one class

4 because of their spatial dominancy and popular cropping practices of corn-soybean

5 rotation in the Midwest. Each of other CDL classes in Table 2 is also assigned to its

6 corresponding factor value. For example, in the category of "Other crops", winter wheat

7 and spring wheat have a C-Factor of 0.3 and safflower has a C-Factor of 0.26 (Ziv et al.

8 2012). For the P-Factor, winter wheat and spring wheat have a P-Factor of 0.89 , while

9 safflower has a P-Factor of 0.91. Detailed land management practices such as till or no-

10 till were not considered in this study because these records at regional level were not

11 available.

12 Table 2: The list of $\mathrm{C}$ - and P-Factors in the study region. Defined upon crop types

13 and cropping rotation activities in the CDL map.

14

15

16

17

\begin{tabular}{l|r|r} 
CDL Class & C-Factor & P-Factor \\
\hline Corn, soybean & 0.28 & 0.89 \\
\hline Double crop & 0.003 & 0.89 \\
\hline $\begin{array}{l}\text { Other crops (e.g. winter wheat, spring } \\
\text { wheat) }\end{array}$ & $0.15-0.64$ & $0.88-0.91$ \\
\hline Fallow, idle cropland, barren & 1 & $0.89-1$ \\
\hline Grass, alfalfa, other hay & 0.02 & 0.89 \\
\hline Shrubland & 0.008 & 1 \\
\hline Forests & $0.001-0.006$ & 1 \\
\hline Wetland & 0.003 & 1 \\
\hline Developed lands & $0.001-0.003$ & 1 \\
\hline Open water & 0 & 1 \\
\hline
\end{tabular}

\section{Distance-weighted RUSLE}

To better assess soil erosion potential at a regional level, this study modified the

RUSLE by adding in a wetland/waterbody-related distance factor: the distance to nearest 
1 downstream wetland/waterbody. Following the Environmental Protection Agency

2 (EPA)'s Clean Water Rule (EPA 2016), soil erosion of a cell is assumed influential to a

3 downslope wetland/waterbody within a distance of 4,000 feet (1,219 meters), beyond

4 which it is considered to no longer affect this wetland/waterbody. For a cell at the

5 minimal distance to the downslope wetland/waterbody (90 meters), its soil erosion is

6 assumed to have the highest contribution of 1 . For a cell at or beyond the longest

7 effective distance, its contribution is 0 .

8 Sediment of eroded soil decreases with distance during transportation. Therefore,

9 a $1^{\text {st }}$-order Inverse Distance Weighting (IDW) approach is applied to assign the distance

10 factor. After calculating the distance to the nearest wetland/waterbody of a given cell, its

11 weight is a linear regression between 0 and 1 following the inverse-distance role. This

12 distance-weighted sensitivity component is assumed additive to the soil loss potential of

13 the RUSLE, which is thus modified as:

$$
A_{\text {adjusted }}= \begin{cases}A, & d>1,219 m \\ A+A *\left(\frac{97.095}{d}-0.079\right), & d<1,219 m\end{cases}
$$

15 where $d$ is the cell's distance (in meter) to the nearest downstream wetland/waterbody.

16 The two constants, 97.095 and -0.079 , are the slope and intercept of the linear IDW

17 regression.

18 Finally, the Soil Loss Tolerance is subtracted to calculate the effective soil

19 erosion severity (SES). Soil Loss Tolerance represents a cell's largest amount of soil per

20 unit area that can be eroded in a year while remaining agriculturally productive (ESRI

21 2015b), i.e. the acceptable loss of soil per ha per annum for each cell. The final equation

22 to calculate SES is:

23 Soil Erosion Severity $=A_{\text {adjusted }}-$ Soil Loss Tolerance 
2 are considered tolerable (non-sensitive), while those above are ESLs. Using the soil

3 erosion risk categories from the Organization for Economic Co-Operation and

4 Development (OECD 2013), the ESL ranks in the study region are grouped into:

Tolerable: $\quad$ SES $\leq 0$ (soil erosion is less than Soil Loss Tolerance)

Moderate: $\quad 0<\mathrm{SES} \leq 22$ metric tons/ha/year

High: $\quad 22<$ SES $\leq 33$ metric tons/ha/year

Severe: $\quad$ SES $>33$ metric tons/ha/year

Here the OECD low-risk category is merged into the Moderate rank. These lands are less of concern than the High and Severe ranks in the study region.

\section{Agricultural Land Use Change and ESL assessment}

With the 2008 and 2011 CDL maps, agricultural land use change is assessed to reflect the increased biofuel feedstock in these two representative years. As corn and grasses are the primary bioenergy concern in this study, a "From-To" change table is created to quantify land conversions, especially between grass and corn. Except for corn/soybean, other croplands such as wheat, rice and sorghum are grouped into "other crops". All herbaceous lands such as grasslands, pastures and hayfields are grouped into "grasses". Other lands such as forest, shrubs and urban, are not considered in the statistical analyses. With the distance-weighted RUSLE model, the SES of the study region is calculated and the ESLs (with SES $>0$ ) are ranked to assess the environmental impacts of corn expansion between the two years.

Finally, using the 2011 land use as base layer, a set of agricultural land conversion scenarios are proposed in the study region: corn to grass vs. grass to corn; on ESLs vs. non-ESLs; and at three magnitudes of change: 5\%, 10\%, and 15\%. Points in each 
1 scenario are randomly sampled. Their projected impacts to environmental sensitivity of

2 the study region are evaluated.

\section{3. RESULTS AND DISCUSSION}

\section{$4 \quad 3.1 \quad$ Agricultural Land Use Change (2008 to 2011)}

5 Corn and soybean are the major crops of the study region and their acreages have 6 expanded from 2008 to 2011 (Fig.2). Corn expansion occurred on the outskirts of the

7 Corn Belt. Interestingly, different trends of land conversion were observed in the west

8 and east of the region. In the Missouri River Basin, new corn/soybean areas were mostly

9 converted from non-grass lands (other crops). In the east of the study region, including

10 the lower end of the Missouri River Basin and across the Upper Mississippi River Basin,

11 corn/soybean conversions were mostly from grasses. These trends indicate different land

12 management policies of the Midwestern states. Even with the great potential of cellulosic

13 ethanol, new establishments of perennial grasses were limited in the study region.

14 Agricultural land use change also occurred among other crops. Their spatial extents are 15 much less than corn/soybean and grasses, and therefore, are not mapped in Fig.2.

16 For planting areas, corn/soybean increased nearly $70,000 \mathrm{~km}^{2}$ in $2008-2011$.

17 There was much higher conversion from grass to corn/soybean $\left(44,178 \mathrm{~km}^{2}\right)$ than from

18 corn/soybean to grass $\left(16,009 \mathrm{~km}^{2}\right)$. Conversion between other crops and corn/soybean

19 was roughly balanced although there was slightly more change from other crops to

20 corn/soybean $\left(25,384\right.$ vs. $\left.17,593 \mathrm{~km}^{2}\right)$. A large area of grasslands was also shifted to

21 other crops. Examination of the CDL maps showed that it was related to wheat expansion

22 in western states such as Kansas, Nebraska and Dakotas in the Great Plains. As wheat 
1 acreages were much lower in the study region and were not our primary interest, these

2 wheat-related land use changes were not discussed in this study.

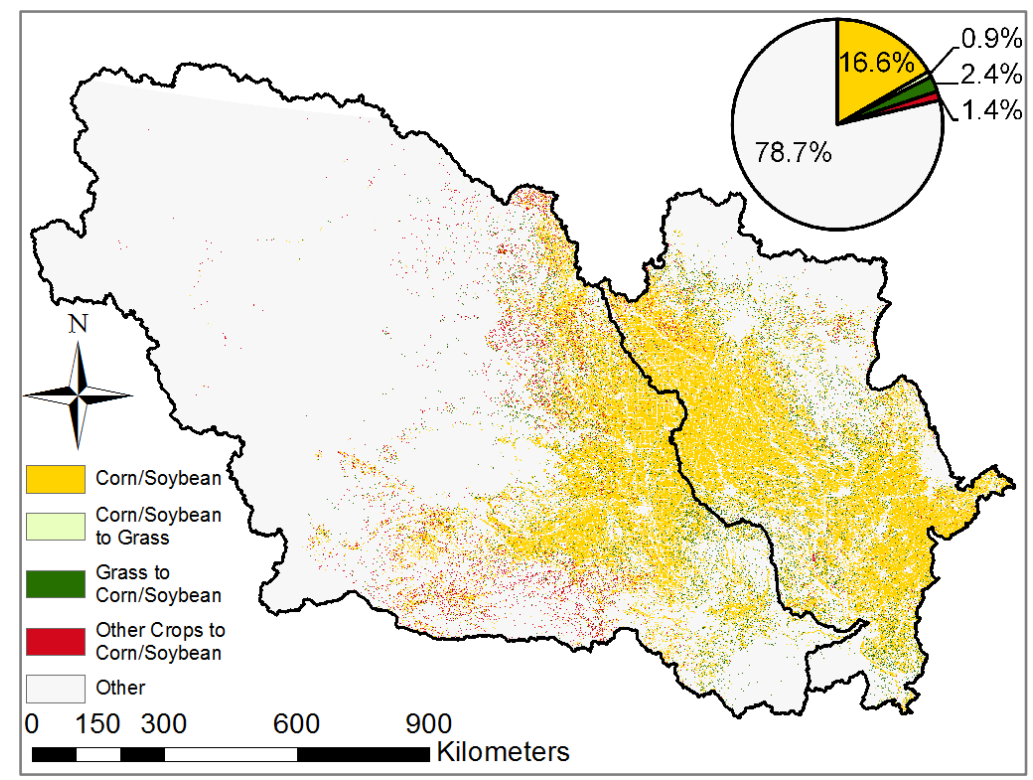

Figure 2: Agricultural Land use change from 2008 to 2011. Only changes related to corn/soybean and grasses are displayed.

\subsection{Soil Erosion Severity (2008 to 2011)}

Using the 2011 data as example, the six input factors of the distance-weighted RUSLE model are mapped in Fig. 3. Note that only C-Factor and P-Factor change with annual agricultural land uses. All other factors remain stable in two years.

The R-Factor (Fig. 3A) reveals the geographically varying trend (increasing from west to east) of precipitation and runoff in the study region. Fig. 3B shows the spatial variation of soil erodibility determined by soil properties. The study region is relatively flat except the rolling terrain of the Great Plains, which controls the topography factor across the region (Fig. 3C). The C-Factor (Fig. 3D) and P-Factor (Fig. 3E) maps indicate that croplands have higher erosion potentials than natural land covers. Wetlands in the northeast and shrublands in the west had high soil prevention capacities. Fig. 3F is the 
1 distance map to identify areas within 1,219 m distance to the nearest downstream

2 wetland/waterbody. These areas were weighted into the RUSLE model to reflect their

3 environmental impact to wetlands and waterbodies. Areas with distance longer than

$4 \quad 1,219$ m (white in Fig.3F) were not influential to model simulation.
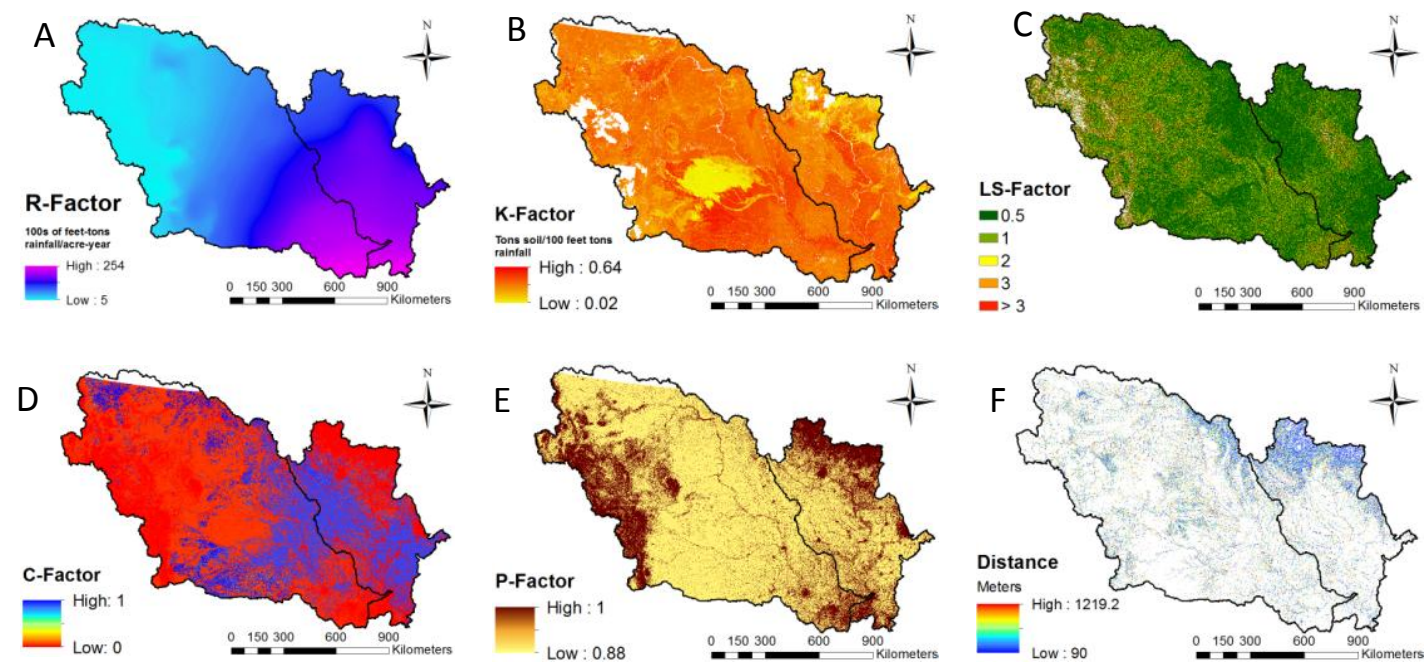

Figure 3 The input factor maps in 2011. (A) R-rainfall and runofffactor; (B) K-soil erodibility factor; (C) LS-topography factor; (D) C-cover factor; $(E) P$-erosion prevention factor; and $(F)$

Distance-the wetland related distance factor.
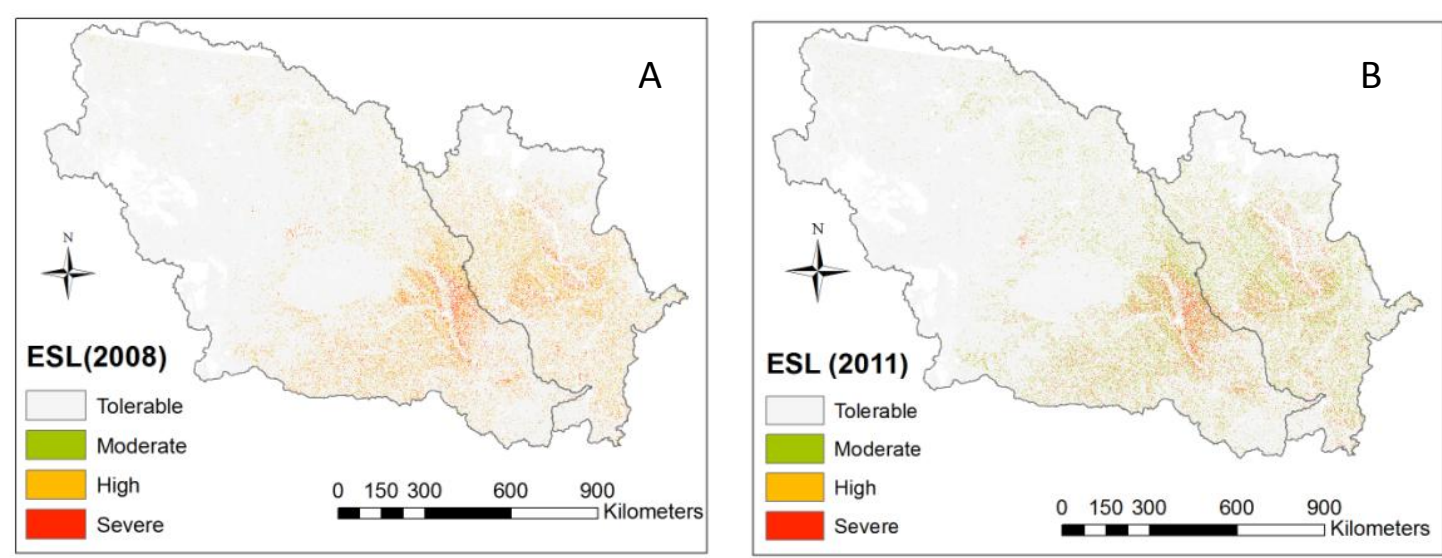

Figure 4: The ESL distributions in three ranks of the study region in $2008(A)$ and 2011 (B).

The majority (over 92\%) of the region had tolerable soil, i.e., not environmentally

sensitive (Fig. 4). The ESL ranks (Moderate, High and Severe) were mostly distributed in 
1 the crop-intensive area in the downstream of the two sub-basins. In 2008, about $4.7 \%$ of

2 the study region experienced Moderate soil erosion, $0.8 \%$ High and $1.5 \%$ Severe soil

3 erosion (Fig.4A). In 2011, areas of all ESL ranks increased, reaching 5.2\%, 0.9\% and

$4 \quad 1.8 \%$ for Moderate, High, and Severe erosion, respectively (Fig.4B).

5 Although the ESL increase in 2008-2011 was not spatially predominant, the

6 percent increase of each rank was dramatic. The ESLs increased $10.71 \%$ in the Moderate,

$7 \quad 16.68 \%$ in the High, and $20.83 \%$ in the Severe rank. The net decrease of tolerable lands

8 was about $15,000 \mathrm{~km}^{2}$, indicating that the Midwest was becoming more environmentally

9 sensitive.

Table 3: The "From-To" Change Table of tolerable lands and three ranked ESLs in

$11 \quad 2008-2011\left(\mathrm{~km}^{2}\right)$.

12

13

14

15

16

17

18

19

20

\begin{tabular}{|c|c|c|c|c|c|}
\hline & \multicolumn{4}{|c|}{ To (2011) } \\
\hline & & Tolerable & Moderate & High & Severe \\
\hline \multirow{4}{*}{ 氙 } & Tolerable & $1,466,338$ & 21,164 & $\mathbf{3 , 8 3 4}$ & 7,640 \\
\hline & Moderate & 12,459 & 61,238 & 475 & 1,651 \\
\hline & High & 1,840 & 415 & 9,595 & 247 \\
\hline & Severe & 3,279 & 1,130 & 210 & 18,997 \\
\hline
\end{tabular}

As shown in the change table (Table 3), the majority of tolerable lands remained tolerable in two years. Interestingly, the highest change occurred between each ESL rank and the tolerable lands. In each rank, more lands were shifted from tolerable lands in 2008 to ESLs in 2011 (the bolded numbers in the first line of Table 3) than the opposite way (the bolded numbers in the first column of Table 3). For example, a total area of $21,164 \mathrm{~km}^{2}$ was changed from tolerable to Moderate ESLs while only $12,459 \mathrm{~km}^{2}$ were shifted back. The changes between ESL ranks were limited. Therefore, it was reasonable to suggest that the increased ESLs in 2011 mostly occurred on tolerable lands in 2008, 
1 possibly as a result of corn expansion in originally non-sensitive croplands. This agreed

2 with the conversion of grass and other crops to corn/soybean on the outskirts of the Corn

3 Belt (as shown in Fig.2). Specifically for corn/soybean acreages, there was an apparent

4 decrease in tolerable lands and increase in all ESL ranks (Table 4), indicating that more

5 erosion-prone lands were being utilized. Grasses predominantly grew in tolerable lands.

6 Their ESL percentages were limited and relatively stable in two years.

7 Table 4: Summary of corn/soybean and grasslands in tolerable and three ranked ESLs in 8 2008-2011, in percentage against the study region.

\begin{tabular}{|l|r|r|r|r|r|}
\hline $\begin{array}{l}\text { Cover } \\
\text { Type }\end{array}$ & Year & Tolerable & Moderate & \multicolumn{1}{l|}{ High } & Severe \\
\hline \multirow{3}{*}{ Corn/Soy } & 2008 & $76.11 \%$ & $15.38 \%$ & $2.88 \%$ & $5.63 \%$ \\
\cline { 2 - 6 } & 2011 & $75.48 \%$ & $15.42 \%$ & $3.00 \%$ & $6.10 \%$ \\
\hline \multirow{3}{*}{ Grass } & 2008 & $98.71 \%$ & $1.12 \%$ & $0.06 \%$ & $0.11 \%$ \\
\cline { 2 - 6 } & 2011 & $98.72 \%$ & $1.12 \%$ & $0.06 \%$ & $0.10 \%$ \\
\hline
\end{tabular}

For management perspectives, it is useful to assess soil erosion severity at watershed levels. Dividing the study region into unit watersheds in hydrologic unit code (HUC) 8, percent covers of ESLs in each watershed were summarized and their changes in two years were calculated. In 2008, there was an average ESL percent of $6.71 \%$ per watershed that increased to $7.61 \%$ in 2011 . In Fig.5A, watersheds with higher ESL covers are mostly in cultivated lands in the lower Missouri River Basin and across the Upper Mississippi River Basin. The ESLs in the Great Plains were less than $2.5 \%$. Assuming the ESL percent changes of all units between 2008 and 2011 were normally distributed, the standard score (Z-score) of each watershed was calculated to assess how many standard deviations its ESL change was away from the average change of all watersheds. Those with significant ESL changes under the confidence intervals of $85 \%$ $(Z>1.44), 90 \%(Z>1.65)$, and $95 \%(Z>1.96)$ are marked in color in Fig.5B. These 
1 areas were located in the downstream of both sub-basins. Statistical analyses revealed the

2 severity of corn expansion-induced soil erosion in this area. There were no watersheds

3 with $\mathrm{Z}<-1.44$, meaning that the negative change was not significant, i.e. environmental

$4 \quad$ sustainability was not improved in 2008-2011.
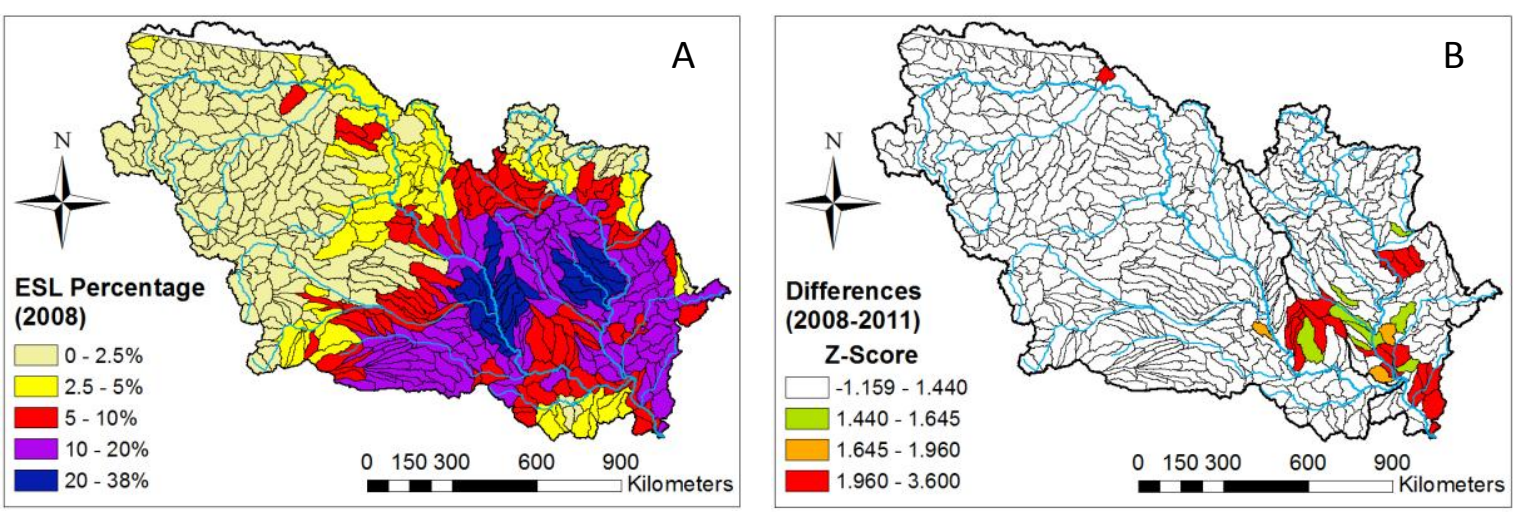

7

Figure 5: Percent covers of ESLs in HUC 8 watersheds in 2008 (A); and watersheds with significant ESL changes in 2008-2011 (B).

\subsection{Sensitivity Analysis}

Among the RUSLE input factors, the K-Factor was related to soil properties, the

R-Factor relied on the 30-year average precipitation, and the LS-Factor was determined by topography. Only C- and P-Factors varied spatially and temporally with bioenergy land use change in the study region. Therefore, we performed sensitivity analysis of these two factors using three pre-selected HUC-8 watersheds as test sites (marked in Fig.1). As shown in the CDL maps in 2011, the test watershed \#1 (TS-1) is located in a grassdominated, tolerable prairie land in North Dakota (Fig.6A-1). The test watershed \#2 (TS2) is located within the BCAP land in Missouri, having a mixture of corn/soybean fields and pasturelands (Fig.6B-1). The test watershed \#3 (TS-3) is located in Iowa in the heart of the Corn Belt, predominantly covered with corn/soybean fields (Fig.6C-1). 
1

2

3

4

5

6

7

8

9

10
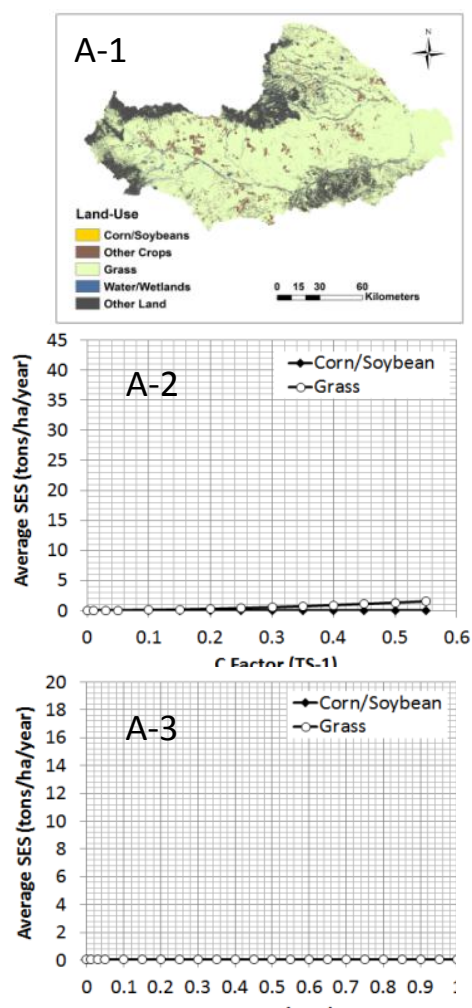

P Factor (TS-1)
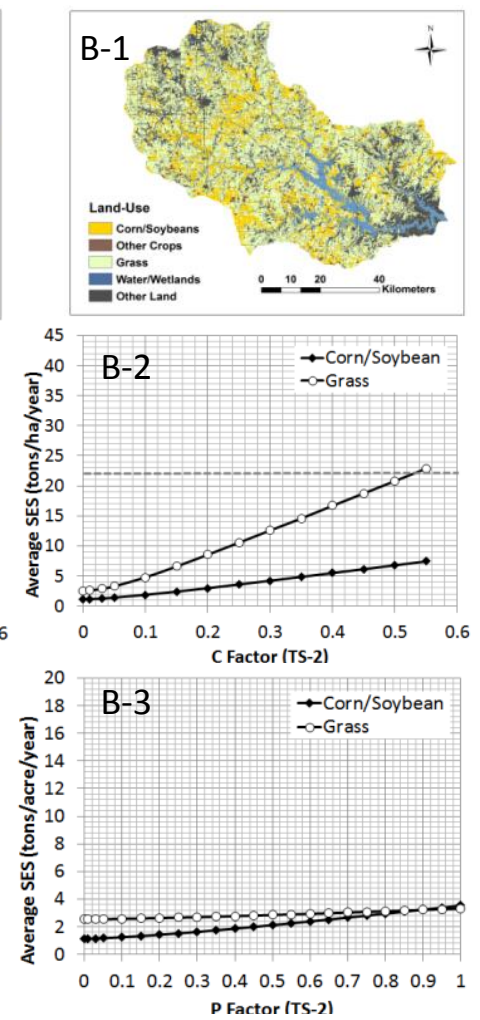
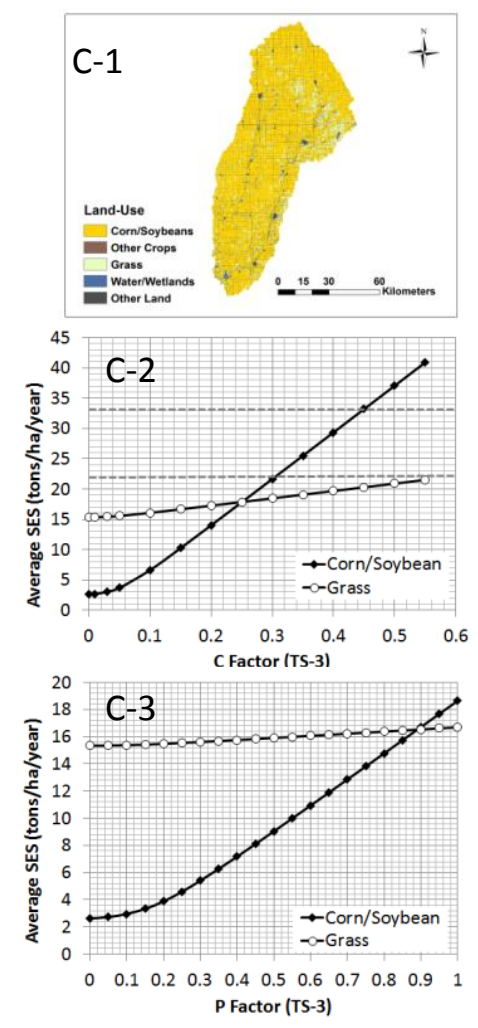

Figure6: The 2011 CDL maps of the three test watersheds (TS) and their sensitivity plots of $C$ - and P-Factors. The High and Severe threshold lines, SES=22 and SES=33 (metric tons/ha/year), are marked in applicable plots.

Fig.6 also outlines the simulated average SES of each test watershed. While all other factors remaining the same as in Table2, with a given $\mathrm{P}$ - or C-Factor value, the RUSEL model was run in each watershed and the pixel-level SES outputs were averaged to represent the SES of this watershed. Only P- and C-Factors of corn/soybean and grass were examined in the simulation, one at each time. Referring to past studies in agricultural soil erosion (literature listed in Table 1), we assigned the C-Factor to a range of $0-0.55$ and the P-Factor to a range of $0-1$ for the sensitivity analyses. For any pixel with the SES output less than 0, it was assigned to 0. Therefore the averaged SES values in Fig.6 are always positive. 
In the study region, corn and soybean were assigned a C-Factor $=0.28$ and $\mathrm{P}$

$2=0.89$; grass was assigned a C-Factor $=0.02$ and $\mathrm{P}=0.89$ (as listed in Table 2). In TS-1,

3 prairie grasses covered $68.6 \%$ of the watershed while corn/soybean was only $0.03 \%$.

4 Therefore, the contribution of corn/soybean cultivation to soil loss was limited. A larger

5 C-Factor of grass contributed more to soil erosion, but the resulted SES value remained

6 low (Fig.6A-2). Soil erosion was not sensitive to P-Factor in this watershed (Fig.6A-3).

7 In TS-2, pasturelands covered 50.35\% and corn/soybean had 18.46\%. Soil erosion was

8 much more sensitive to the C-Factor increment of grass than that of corn/soybean

9 (Fig.6B-2). When the C-Factor of grass reached 0.55, the land changed to the High rank

10 ESL (SES > 22 metric tons/ha/year). Soil erosion was not sensitive to the P-Factor in this

11 mixed watershed (Fig.6B-3). In TS-3, the cover of corn/soybean reached $77.1 \%$ while

12 grasslands were only $9.1 \%$ of the watershed. The contribution of grass to soil loss was

13 thus limited. The SES was highly sensitive to both factors of corn/soybean. When its C-

14 Factor increased from 0.28 (default) to 0.3 , the SES reached 22 metric tons/ha/year, i.e.

15 changing from the Medium to High rank ESL (Fig.6C-2). It quickly converted to the

16 Severe rank (SES > 33 metric tons/ha/year) when the C-Factor increased to 0.45 . The

17 SES was also sensitive to the P-Factor of corn/soybean although its increment was less

18 dramatic than that of the C-Factor (Fig.6C-3).

19 In short, both C- and P-Factors were related to soil erosion in agricultural lands of

20 the study region. Upon our experiments in three test watersheds, soil erosion was more

21 sensitive to the C-Factor, especially in cultivated watersheds (mixed or corn/soybean

22 dominated). Applying to the Midwest, our approach effectively extracted environmental 
1 sensitivities under different land use practices, and therefore, provided meaningful spatial

2 patterns of agriculture-driven ESLs in such as large region.

\section{$3 \quad 3.4$ Soil Erosion Severity under Projected Bioenergy Land Use Change}

4

5

Using the 2011 land use as baseline, the impacts of agricultural land use change to soil erosion were simulated on non-ESLs and ESLs in steps of 5\%, 10\% and $15 \%$ change (Fig.7). In each step, a certain number of pixels to assign new land uses were randomly extracted across the study region. When converting grass to corn on non-ESLs, tolerable lands decreased but all ESL ranks linearly increased with higher percent of land use change. When $15 \%$ of grasslands in the study region were converted to corn, the Severe rank ESLs increased up to $15.71 \%$ and the High rank up to $18.27 \%$, indicating high sensitivity of soil erosion to decreased grass covers even on currently tolerable lands. When converting corn to grass on non-ESLs, however, there was virtually no change in any ESL rank.

15

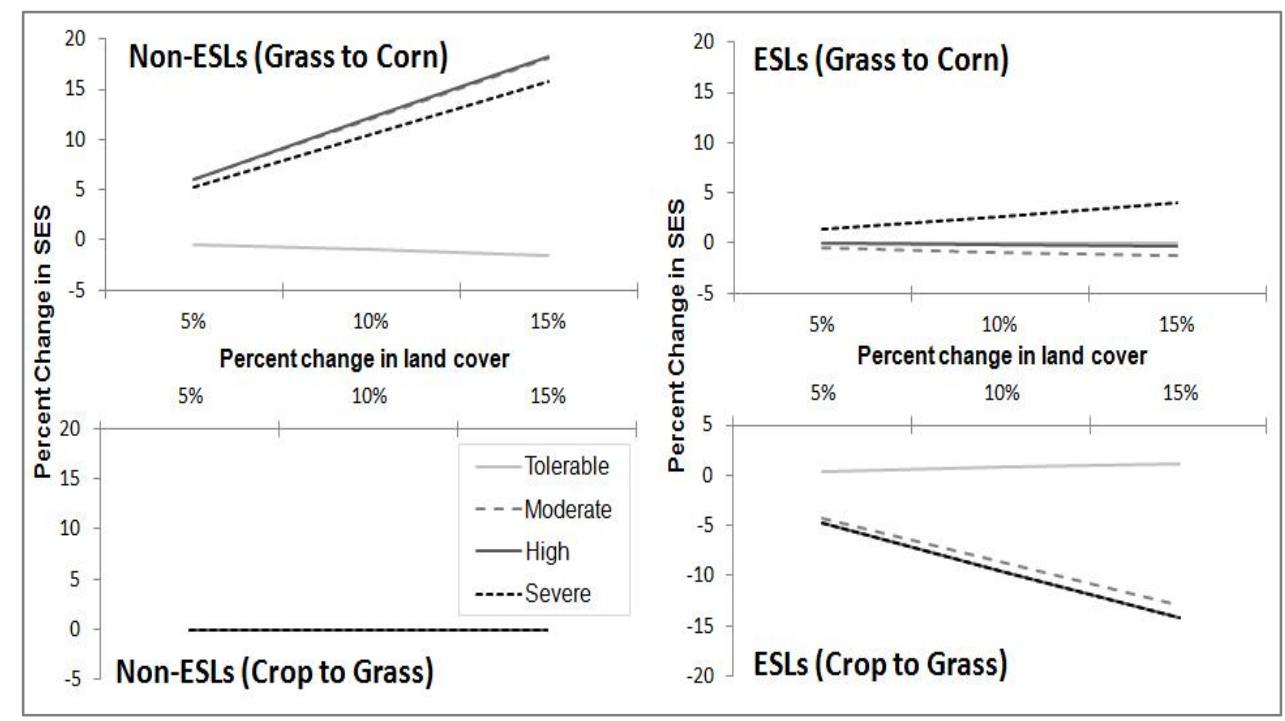

Figure 7 Percent change of ESLs under projected land use change on non-ESLs and ESLs. The upper charts are grass to corn, and the lower charts are corn to grass. 
On ESLs in Fig.7, percent changes of all ESL ranks are low when converting

2 grass to corn. The Severe rank was most sensitive, which increased $4.0 \%$ when $15 \%$ of

3 grasslands were converted to corn fields. When converting corn to grass on ESLs, it

4 showed dramatic decreases in all ESL ranks. The Severe rank decreased $14.22 \%$ when

$515 \%$ of corn was converted to grasslands. Correspondingly there was an increase of

6 tolerable lands. Therefore, in accordance with conservation programs such as CRP and

7 BCAP, the best practice of reducing soil erosion is to convert annual crops back to

8 grasslands on environmentally sensitive lands.

9 Corn/soybean cropping is the dominant agricultural land use in the Midwest, and

10 has experienced dramatic expansion triggered by accelerating biofuel demand. While

11 perennial native grasses have been investigated as an alternative energy crop for several

12 decades, this study reveals that there is still a higher acreage of grasslands converted to

13 corn/soybean than corn/soybean to grasslands in 2008-2011, resulting in a decrease of

14 permanent cover in agricultural lands. This, in turn, increases soil erosion and

15 environmental sensitivity of the region. While ESLs in the Midwest are still spatially

16 limited, our study shows that the area of tolerable land decreased from 2008 to 2011,

17 supporting the idea that environmental sensitivity of this land is highly influenced by

18 agricultural usage (Allen and Vandever 2003).

19 Our study also indicates different impacts of agricultural land use change on

20 tolerable lands and ESLs. On tolerable lands, the conversion of grass to corn can

21 significantly increase soil erosion severity in all ESL ranks. This confirms the importance

22 of grass cover to maintain tolerable levels of soil erosion even on tolerable lands. On

23 ESLs, converting corn to grass does not increase the area of tolerable lands but the ESL 
1 ranks are significantly improved (e.g. from Severe to High), indicating the necessity of

2 re-planting perennial grasses in currently corn-dominated ESLs. This has profound

3 implications for bioenergy expansion in the U.S. Midwest, as corn ethanol from

4 expanded croplands is indicated to be unsustainable on both ESLs and non-ESLs of the

5 region. Once the feedstock conversion techniques improve, resulting in reduce costs,

6 native prairie grass used for biofuel could become an optimal solution to reduce the

7 environmental sensitivity of the region.

8 This study integrates satellite-extracted land uses, GIS, and hydrology models to

9 provide a regional assessment about the impacts of corn expansion on the sustainability

10 of the U.S. Midwest. In comparison with field-specific or watershed-level studies in past

11 literature, one advantage of this study is its spatial investigation of bioenergy

12 development at a river-basin level. This provides a regional overview for better

13 understanding about environmental impacts of corn expansion. Different impacts of

14 agricultural land use change (corn to grass or grass to corn) are observed in currently ES

15 lands. This may assist site selection of land use change for decision making of bioenergy

16 industry as well as environmental conservation.

17 Uncertainties may rise from data availability and modeling performance across

18 such a large region, for example classification errors of CDL maps and information loss

19 when re-sampling environmental data in different cell sizes. Also, the RUSLE model

20 does not take weather anomalies and climate change into account. Different thresholds of

21 acceptable soil loss tolerance may also affect the areal coverage of ESLs. Actually,

22 studies have debated that the current threshold of soil loss tolerance was set too high

23 (Johnson 1987). If the soil loss tolerance were to be lowered, more lands would be 
1 defined environmentally sensitive in the study region. Finally, future work may take

2 advantage of more frequent satellite observations, such as the daily $36-\mathrm{km}$ soil moisture

3 products collected by the new Soil Moisture Active Passive (SMAP) satellite launched in

4 2015. A timely soil moisture layer in growing season may provide improved input data,

5 such as runoff and soil erodibility, for model simulation. More quantitative land surface

6 properties, e.g. crop production and perennial biomass from remote sensing imagery, may

7 also improve our assessment of environmental resilience and sustainability of this

8 important agricultural region.

9

\section{4. CONCLUSIONS}

This study explores agricultural land use change fueled by corn expansion in the

12 U.S. Midwest and its impacts to environmental sensitivity. A distance-weighted RUSLE

13 model is developed to include downstream wetlands and waterbodies for environmental

14 assessment. With satellite-classified CDL crop maps, soil erosion severity across the

15 study region is extracted and ranked. From 2008 to 2011, corn/soybean acreages increase

16 dramatically at the cost of grasslands and other crops. The conversion radiates outward

17 from the Corn Belt and reflects different land uses in the two sub-basins. Within

18 scenarios of bioenergy land use change (corn to grass, grass to corn) on both non-ESL

19 and ESLs, soil erosion severity is projected with a change rate of 5\%, $10 \%$ and $15 \%$,

20 respectively. Results suggest maintaining grass cover on non-ESLs and converting corn

21 to grass on ESLs to improve environmental sustainability. By identifying the ESLs in

22 High and Severe ranks, this study reveals optimal sites for re-establishing native prairie

23 grasses as a sustainable energy crop in the Midwest. 
Acknowledgements: This research is supported by Agriculture and Food Research

Initiative Competitive Grant no. 2012-67009-22137 from the USDA National Institute of

Food and Agriculture. We thank the USDA NASS for the CDL products in 2008 and

2011 that serve as valuable reference in this research.

\section{REFERENCES}

Allen, A. W. and Vandever, M. W., 2003. A national survey of Conservation Reserve Program (CRP) participants on environmental effects, wildlife issues, and vegetation management on program lands. Biological Science Report USGS/BRD/BSR-20030001, Denver, Colorado.

Boryan, C., Yang, Z., Mueller, R. and Craig, M., 2011. Monitoring US agriculture: the US Department of Agriculture, National Agricultural Statistics Service, Cropland Data Layer Program. Geocarto International 26, 341-358.

Brown, J. P., Weber, J. G. and Wojan, T. R., 2013. Emerging energy industries and rural growth. ERR-159. USDA Economic Research Service, Washington D.C.

Das, M. K., Fuentes, R. G. and Taliaferro, C. M., 2004. Genetic variability and trait relationships in switchgrass. Crop Science 44, 443-448.

EPA, 2016. Factsheet - Clean Water Rule. Available at http://www.epa.gov/cleanwaterrule. Last accessed on April 6, 2016.

ERS (Economic Research Service), 2016. U.S. Bioenergy Statistics. Available at http://www.ers.usda.gov/data-products/us-bioenergy-statistics.aspx. Last accessed on May 5, 2016.

ESRI, 2015 a. USA Soils Erodibility Factor. Available at http://www.arcgis.com/home/item.html?id=93be1788338d492e8d9079abb65d5722. Last accessed on September 28, 2015.

ESRI, 2015 b. USA Soil Loss Tolerance Factor. Available at http://www.arcgis.com/home/item.html?id=ef1e2d7ba93940b58c4f8e8d9b6514d0. Last accessed on September 17, 2015.

Hopkins, A. A., Vogel, K. P., Moore, K. J., Johnson, K. D., and Carlson, I. T., 1995. Genotypic variability and genotype $\times$ environment interactions among switchgrass accessions from the Midwestern USA. Crop Science 35, 565-571.

Johnson, L. C., 1987. Soil loss tolerance: fact or myth? Journal of Soil and Water Conservation 42, 155-160.

Kim, J. B., Saunders, P. and Finn, J. T., 2005. Rapid assessment of soil erosion in the Rio Lempa Basin, Central America, using the Universal Soil Loss Equation and geographic information systems. Environmental Management 36, 872-885. 
Kort, J., Collins, M. and Ditsch, D., 1998. A review of soil erosion potential associated with biomass crops. Biomass and Bioenergy 14, 351-359.

Kouli, M., Soupios, P. and Vallianatos, F., 2009. Soil erosion prediction using the Revised Universal Soil Loss Equation (RUSLE) in a GIS framework, Chania, Northwestern Crete, Greece. Environmental Geology 57, 483-497.

Mitasova, H., Hofierka, J., Zlocha, M. and Iverson, L. R., 1996. Modelling topographic potential for erosion and deposition using GIS. International Journal of Geographic Information System 10, 629-641.

NASS CDL (National Agricultural Statistics Service Cropland Data Layer), 2016. CropScape and Cropland Data Layer. USDA-NASS, Washington, D.C. Available at http://nassgeodata.gmu.edu/CropScape/. Last accessed on April 6, 2016.

Ndubisi, F., DeMeo, T. and Ditto, N. D., 1995. Environmentally sensitive areas: a template for developing greenway corridors. Landscape and Urban Planning 33, 159-177.

Nelson, T., Mazurek, D., Ruesch, A., Kempen, S. and Evans, D., 2014. Erosion vulnerability assessment for agricultural lands. Available at http://dnr.wi.gov/topic/nonpoint/documents/evaal/evaal_methods_v1_0.pdf. Last accessed on April 11, 2016.

NRCS, 2004. Universal Soil Loss Equation (USLE). RI FOTG Section I-C. Available at https://efotg.sc.egov.usda.gov/references/public/RI/section1(USLE).pdf. Last accessed April 11, 2016.

OECD, 2013. OECD compendium of agri-environmental indicators. OECD Publishing. DOI: $10.1787 / 9789264181151-$ en.

Panagos, P., Borrelli, P., Meusburger, K., Alewell, C., Lugato, C. and Montanarella, L., 2015. Estimating the soil erosion cover-management factor at the European scale. Land Use Policy 48, 38-50.

Pandey, A., Chowdary, V. M. and Mal, B. C., 2007. Identification of critical erosion prone areas in the small agricultural watershed using USLE, GIS and remote sensing. Water Resources Management 21, 729-746.

Park, S., Oh, C., Jeon, S., Jung, H. and Choi, C., 2011. Soil erosion risk in Korean watersheds, assessed using the revised universal soil loss equation. Journal of Hydrology 399, 263-273.

Parveen, R. and Kumar, U., 2012. Integrated approach of Universal Soil Loss Equation (USLE) and Geographical Information System (GIS) for soil loss risk assessment in Upper South Koel Basin, Jharkhand. Journal of Geographic Information System 4, 588-596.

Renard, K. G., Foster, G. R., Weesies, G. A. and Porter, J. P., 1991. RUSLE - revised universal soil loss equation. Journal of Soil and Water Conservation 46, 30-33.

Smeets, E. M. W., Lewandowski, I. M. and Faaij, A. P. C., 2009. The economical and environmental performance of miscanthus and switchgrass production and supply 
chains in a European setting. Renewable and Sustainable Energy Reviews 13, 12301245 .

Sojka, R. E., Langdale, G. W. and Karlen, D. L., 1984. Vegetative techniques for reducing water erosion of cropland in the southeastern United States. Advances in Agronomy 37, 155-181.

Somma, D., Lobkowicz, H. and Deason, J. P., 2010. Growing America's fuel: an analysis of corn and cellulosic ethanol feasibility in the United States. Clean Techn. Environ. Policy 12, 373-380.

Vogel, K. P., Brejda, J. J., Walters, D. T. and Buxton, D. R., 2002. Switchgrass biomass production in the Midwest USA: harvest and nitrogen management. Agronomy Journal 94, 413-420.

Wallander, S., Claassen, R. and Nickerson, C., 2011. The ethanol decade: an expansion of U.S. corn production, 2000-2009, EUB-79, USDA Economic Research Service, available at http://www.ers.usda.gov/media/121204/eib79.pdf. Last accessed on July 11, 2016.

Wang, C., Zhong, C. and Yang, Z., 2014. Assessing bioenergy-driven agricultural land use change and biomass quantities in the U.S. Midwest with MODIS time series. J. Appl. Remote Sens. 8 (085198), 1-16.

Wang, C., Fan, Q., Li, Q., SooHoo, W. M. and Lu, L. (In review). Energy crop mapping with enhanced TM/MODIS time series in the BCAP agricultural lands. Submitted to ISPRS Journal of Photogrammetry and Remote Sensing.

Williams, J. R. and Berndt, H. D., 1977. Sediment yield prediction based on watershed hydrology. Trans. Am. Soc. Agric. Engrs 20, 1100-1104.

Wischmeier, W. H. and Smith, D. D., 1960. A universal soil-loss equation to guide conservation farm planning. Trans. Int. Congr. Soil Sci. 7, 418-425.

Wischmeier, W. H. and Smith, D. D., 1978. Predicting rainfall erosion losses: a guide to conservation planning. Agriculture Handbook 282. U.S. Department of Agriculture. Washington, DC.

Wright, L. L., 2007. Historical perspective on how and why switchgrass was selected as a "model" high-potential energy crop. OENL/TM-2007/109, Oak Ridge National Laboratory, Oak Ridge, Tennessee.

Yang, W., Liu, Y., Ou, C. and Gabor, S., 2016. Examining water quality effects of riparian wetland loss and restoration scenarios in a southern Ontario Watershed. Journal of Environmental Management 174, 26-34.

Ziv, G., Ghebremichael, L, Sharma, M., Eichelberger, B. and Conte, M., 2012. Biofuel expansion impacts on soil loss in the US Midwest. Available at http://www.naturalcapitalproject.org/pubs/BiofuelEPAReport.pdf. Last accessed on April 10, 2016. 

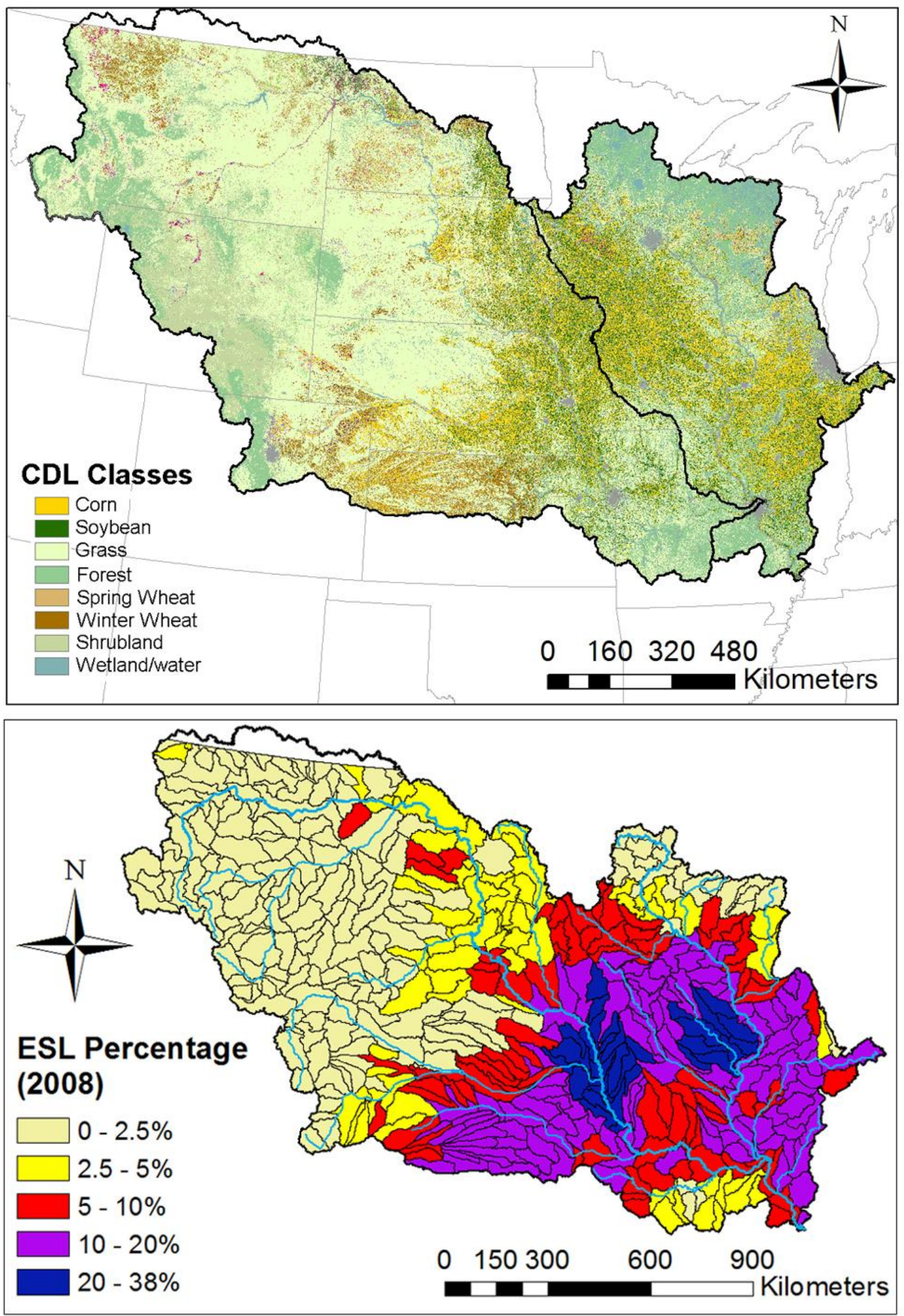

Croplands and Environmental Sensitive Lands in the U.S. Midwest 